\title{
Hubungan Antara Kepuasan Kerja Dengan Kinerja Karyawan
}

Oleh:

Mella Susanti

(17002092)

\section{Jurusan Administrasi Pendidikan \\ Fakultas Ilmu Pendidikan \\ Universitas Negeri Padang}

\author{
Email: \\ Mella17susanti@gmail.com
}

\begin{abstract}
ABSTRAK
Kepuasan kerja dan kinerja merupakan suatu hubungan yang berkaitan pada sebuah organisasi. Kepuasan kerja akan tercapai bila kebutuhan karyawan terpenuhi melalui pekerjaan. Dimana kepuasan kerja merupakan keadaan emosi yang senang atau emosi positif yang berasal dari penilaian pekerjaan atau pengalaman seseorang. Dengan kepuasan kerja yang tinggi akan meningkatkan kinerja karyawan terhadap organisasi tempat mereka bekerja. adanya hubungan timbal balik antara kinerja dan kepuasan kerja. Di satu sisi dikatakan kepuasan kerja menyebabkan peningkatan kinerja sehingga pekerja yang puas akan lebih produktif. Disisi lain dapat pula terjadi kepuasan kerja disebabkan oleh adanya kinerja atau prestasi kerja sehingga pekerja yang lebih produktif akan mendapatkan kepuasan.
\end{abstract}

Kata kunci: kepuasan kerja, kinerja karyawan

\section{A. PENDAHULUAN}

kepuasan kerja merupakan dambaan setiap invididu yang sudah bekerja. Masingmasing karyawan memiliki tingkat kepuasan yang berbeda sesuai dengan nilai yang dianutnya. Semakin banyak aspek aspek dalam pekerjaan yang sesuai dengan keinginan dan 
kebutuhan karyawan tersebut maka semakin tinggi pula kepuasan yang dirasakan, demikian sebaliknya.

Robbins dan Judge (2015) menjelaskan dari tinjauan atas 300 studi menyatakan terdapat korelasi yang cukup kuat antara kepuasan kerja dan kinerja. Dimana saat kita berpindah dari level individu ke organisasi, kita juga menemukan dukungan untuk hubungan kepuasan-kinerja. Saat kita mengumpulkan data kepuasan dan kinerja untuk organisasi secara keseluruhan, kita menemukan bahwa organisasi dengan lebih banyak pekerja yang lebih puas cenderung lebih efektif dibandingkan organisasi yang lebih sedikit.

Kepuasan kerja karyawan didefenisikan sebagai reaksi dan perasaan seseorang terhadap tempat ia bekerja. Kepuasan kerja karyawan merupakan hal yang bersifat individual tentang perasaan seseorang terhadap pekerjaannya. Tingkat kepuasan yang berbeda-beda pasti dimiliki oleh setiap individu.

Keberhasilan suatu organisasi sangat dipengaruhi oleh kinerja karyawannya. Setiap organisasi maupun perusahaan akan selalu berusaha untuk meningkatkan kinerja karyawan, dengan harapan apa yang menjadi tujuan perusahaan akan tercapai. Salah satu cara yang ditempuh oleh perusahaan dalam meningkatkan kinerja karyawannya, misalnya dengan melalui pendidikan, pelatihan, pemberian kompensasi yang layak, pemberian motivasi, dan menciptakan lingkungan kerja yang kondusif serta memilki disiplin. Peningkatan kinerja karyawan akan membawa kemajuan bagi perusahaan untuk dapat bertahan dalam suatu persaingan lingkungan bisnis yang tidak stabil.

Oleh karena itu upaya-upaya untuk meningkatkan kinerja karyawan merupakan tantangan manajemen yang paling serius karena keberhasilan untuk mencapai tujuan dan kelangsungan hidup perusahaan tergantung pada kualitas kinerja sumber daya manusia yang ada di dalamnya.

Kinerja adalah hasil kerja yang dapat dicapai oleh seseorang atau sekelompok orang dalam suatu organisasi, sesuai dengan wewenang dan tanggung jawab masingmasing dalam rangka upaya mencapai tujuan organisasi yang bersangkutan secara legal, tidak melanggar hukum dan sesuai dengan moral maupun etika. Jadi kinerja merupakan hal yang penting bagi perusahaan atau organisasi. Usaha untuk meningkatkan kinerja karyawan, diantaranya dengan memperhatikan lingkungan kerja. Lingkungan kerja merupakan segala sesuatu yang ada disekitar para pekerja yang dapat mempengaruhi dirinya dalam menjalankan tugas-tugas yang dibebankan (Nitisemito, 2000) 
Dalam konteks organisasi publik, kinerja adalah suatu ukuran prestasi / hasil dalam mengelola dan menjalankan suatu organisasi dimana berhubungan dengan segala hal yang akan, sedang dan telah dilakukan organisasi tersebut dalam kurun waktu tertentu.kinerja dapat dibagi menjadi dua kategori, yang pertama adalah in-role performance didefenisikan sebagai kegiatan spesifik dan dituangkan ke dalam job deskription karyawan, lalu selanjutnya di mandatkan, dinilai, dan diberikan penghargaan oleh organisasi. Sejumlah aturan dan prosedur membuat perilaku kerja menjadi terprediksi, sehingga kegiatan utama organisasi dapat dikoordinir dan dikontrol untuk mencapai tujuan organisasi. Kecakapan dan keahlian karyawan untuk mengelola aktivitas dan aturan kerja menjadi komponen variasi yang penting didalam kinerja sebuah organisasi sedangkan innovative performance didefenisikan sebagai niat, promosi dan realisasi dari ide yang berhubungan aturan kerja, kelompok kerja atau organisasi dalam hubungannya dengan capaian keuntungan dari suatu organisasi . tujuan dari utama sebuah organisasi yaitu dapat diharapkan menjadi sumber motivasi yang penting untuk innovative job performance dengan beberapa alasan, yang pertama, individu memiliki kecendrungan untuk melakukan hal-hal yang menantang untuk tugas yang kompleks.

\section{B. PEMBAHASAN TEORI}

\section{Kepuasan kerja}

Menurut Robbins (2003:78) kepuasan kerja adalah sikap umum terhadap pekerjaan seseorang, yang menunjukkan perbedaan antara jumlah penghargaan yang diterima pekerja dan jumlah yang mereka yakini seharusnya mereka terima.

Menurut greeberg dan baron (2003:148) mendesripsikan kepuasan kerja sebagai sikap positif dan negatif yang dilakukan individual terhadap pekerjaan mereka.pandangan senada dikemukakan gibson, ivancevich dan donnelly (2000:106) yang menyatakan kepuasan kerja sebagai sikap yang memiliki pekerja tentang pekerjaan mereka.hal tersebut merupakan persepsi mereka tentang pekerjaan. (Wibowo, 2017)

Menurut kreitner dan kinicki (2001: 224) kepuasan kerja merupakan respons affective atau emosional terhadap berbagai segi pekerjaan seseorang. Defenisi ini menunjukakan bahwa job satisfaction bukan merupakan konsep tunggal.seseorang dapat relatif puas dengan salah satu aspek pekerjaan dan tidak puas dengan satu atau lebih aspek lainnya.

Pekerjaan memerlukan interaksi dengan rekan kerja dan atasan, menigukti peratran dan kebijakan organisasi, memenuhi standar kinerja, hidup dengan kondisi kerja yang sering ideal dan semacamnya. Kepuasan kerja mencerminkan sikap dan bukan perilaku. Kepuasan 
kerja merupakan variabel tergantung karena dua alasan, yaitu: menunjukkan hubungan dengan faktor kinerja dan merupakan preferensi nilai yang dipegang banyak peneliti perilaku organisasi.

Keyakinan bahwa pekerjaan yang puas lebih produktif daripada yang tidak puas menjadi pendirian banyak manajer bertahun-tahun. Namun, banyak kenyataan mempertanyak asumsi hubungan kausah tersebut. Peneliti yang memiliki nilai humanitas yang kuat menolak bahwa kepuasan merupakan tujuan yang legitimate suatu organisasi. Mereka juga menolak bahwa organisasi bertanggung jawab menyediakan pekerjaan yang manantang dan secara intrinsik mengahargai.

\section{Indikator Kepuasan Kerja}

Menurut Luthans (2006), Kelima dimensi tersebut adalah:

1. Pekerjaan itu sendiri adalah terkait dengan karakteristik pekerjaan dan kompleksitas pekerjaan yang dijalankan itu menyenangkan dan memuaskan serta memberikan tantangan kepada karyawan.

2. Pendapatan/gaji adalah sejumlah upah yang diterima di mana hal ini dipandang sebagai hal yang dianggap pantas dibanding dengan orang lain dalam organisasi. Gaji merupakan imbalan tetap yang dibayarkan berupa uang secara berkala atau dengan periode yang tetap, misalnya sebulan sekali.

3. Kesempatan promosi adalah proses perubahan dari suatu pekerjaan ke pekerjaan lain dalam hierarki wewenang dan tanggung jawab yang lebih tinggi daripada wewenang dan tanggung jawab yang telah diberikan pada waktu sebelumnya, dengan kata lain diberikan kesempatan untuk maju dalam organisasi tersebut.

4. Pengawasan adalah hubungan antara setiap karyawan dengan atasan langsung.

5. Rekan kerja adalah teman kerja dalam organisasi dan interaksinya yang bersifat kerjasama dalam pekerjaan.

\section{Kinerja}

(MANGKUNEGARA, 1993) mendefinisikan kinerja karyawan adalah hasil kerja secara kualitas dan kuantitas yang dicapai oleh seseorang karyawan dalam melaksanakan tugasnya sesuai dengan tanggung jawab yang diberikan kepadanya. 
Simamora (2004) menyatakan kinerja mengacu kepada kadar pencapaian tugas-tugas yang membentuk sebuah pekerjaan karyawan.

Kinerja merefleksikan seberapa baik karyawan memenuhi persyaratan sebuah pekerjaan. Kinerja seorang karyawan merupakan hal yang bersifat individual, karena setiap karyawan mempunyai tingkat kemampuan yang berbeda-beda dalam mengerjakan tugasnya. Pihak manajemen dapat mengukur karyawan atas unjuk kerjanya berdasarkan kinerja dari masing-masing karyawan.

Menurut (Ermita \& Rahmayuni, 2019)Pembinaan kinerja sangatlah penting bagi setiap pegawai dalam suatu organisasi , karena dengan adanya pembinaan pemimpin dapat mengetahui atau mengidentifikasi masalah atau kesulitan yang dialami oleh karyawan, serta dengan pembinaan juga menciptakan cara kerja yang maksimal, meningkatkan kualitas, keterampilan serta semangat kerja yang tinggi pada pegawai dan menciptakan ketaatan atas norma dan peraturan yang berlaku didalam organisasi.Faktor-faktor yang mempengaruhi kinerja karyawan dalam organisasi menunjukkan bahwa tujuan yang jelas dan terukur, insentif, motivasi kerja, remunerasi, desentralisasi.

\section{Indikator Kinerja}

Menurut Mathis dan Jackson (2006), pada umumnya terdapat beberapa elemen kinerja karyawan antara lain:

1. Kuantitas dari hasil, diukur dari persepsi karyawan terhadap jumlah aktivitas yang ditugaskan beserta hasilnya.

2. Kualitas dari hasil, diukur dari persepsi karyawan terhadap kualitas pekerjaan yang dihasilkan serta kesempurnaan tugas terhadap ketrampilan dan kemampuan karyawan.

3. Ketepatan waktu dari hasil, diukur dari persepsi karyawan terhadap suatu aktivitas yang diselesaikan dari awal waktu sampai menjadi output. Dapat menyelesaikan pada waktu yang telah ditetapkan serta memaksimalkan waktu yang tersedia.

4. Kehadiran, tingkat kehadiran karyawan dalam perusahaan dapat menentukan kinerja karyawan.

5. Kemampuan bekerja sama, diukur dari kemapuan karyawan dalam bekerjasama dengan rekan kerja dan lingkungannya.

\section{Hubungan kepuasan kerja dengan kinerja pegawai}


Kepuasan kerja adalah sikap emosional yang menyenangkan dan mencintai pekerjannya. Kepuasan kerja dalam pekerjaan adalah kepuasan kerja yang dinikmati dalam pekerjaan dengan memperoleh hasil kerja, penempatan, perlakuan, peralatan dan suasana lingkungan kerja yang baik. Kepuasan diluar pekerjaan adalah kepuasan kerja karyawan yang dinikmati diluar pekerjaan dengan besarnya balas jasa yang akan diterima dari hasil kerjanya, agar dia dapat membeli kebutuhan-kebutuhannya.

Kepuasan kerja akan tercapai bila kebutuhan karyawan terpenuhi melalui pekerjaan. Dimana kepuasan kerja merupakan keadaan emosi yang senang atau emosi positif yang berasal dari penilaian pekerjaan atau pengalaman seseorang. Dengan kepuasan kerja yang tinggi akan meningkatkan kinerja karyawan terhadap organisasi tempat mereka bekerja.

Sementara itu, gibson, ivancevich, dan donnelly (2000:110) secara jelas menggambarkan adanya hubungan timbal balik antara kinerja dan kepuasan kerja. Di satu sisi dikatakan kepuasan kerja menyebabkan peningkatan kinerja sehingga pekerja yang puas akan lebih produktif. Disisi lain dapat pula terjadi kepuasan kerja disebabkan oleh adanya kinerja atau prestasi kerja sehingga pekerja yang lebih produktif akan mendapatkan kepuasan.

\section{KESIMPULAN DAN SARAN}

\section{kesimpulan}

Kepuasan kerja adalah sikap emosional yang menyenangkan dan mencintai pekerjannya. Kepuasan kerja dalam pekerjaan adalah kepuasan kerja yang dinikmati dalam pekerjaan dengan memperoleh hasil kerja, penempatan, perlakuan, peralatan dan suasana lingkungan kerja yang baik. Kepuasan diluar pekerjaan adalah kepuasan kerja karyawan yang dinikmati diluar pekerjaan dengan besarnya balas jasa yang akan diterima dari hasil kerjanya, agar dia dapat membeli kebutuhan-kebutuhannya.

dari penjelasan diatas dapat disimpulkan bahwa adanya hubungan timbal balik antara kepuasan kerja dengan kinerja. Bahwasanya dengan kepuasan kerja yang tinggi akan meningkatkan kinerja karyawan dan sebaliknya dengan kinerja yang lebih produktif akan mendapatkan kepuasan dalam bekerja

\section{Saran}

Berdasarkan kesimpulan yang diuraikan maka dapat diberikan saran-saran seperti pimpinan sebaiknya lebih memperhatikan kepuasan kerja karyawan seperti dengan mempertimbangkan imbalan dan gaji karyawan sesuai dengan usaha yang dilakukan oleh 
karyawan tersebut dan kepuasan kerja yang tercipta kalau sudah dikatakan baik namun harus perlu ditingkatkan lagi agar dapat mendorong kinerja karyawan lebih baik lagi sesuai dengan tujuan organisasi yang ditetapkan.

\section{DAFTAR PUSTAKA}

Effendy, O. U. (1989). Psikologi Manajemen Dan Administrasi. Bandung: Mandar Maju.

Ermita, \& Rahmayuni, M. (2019). pembinaan kinerga pegawai oleh pimpinan atasan langsung di kantor kementrian agama kota bukit tinggi. jurnal bahana manajemen pendidikan, VIII(3), 18.

Hamalik, O. (1993). Psikologi Manajemen. Bandung: PT Trigenda Karya.

Leavitt, H. (1992). Psikologi Manajemen. Jakarta: Erlangga.

MANGKUNEGARA, A. P. (1993). Psikologi Perusahaan. Bandung: Trigenda Karya.

Nitisemito, A. S. (2000). Manajemen Personalia : Manajemen Sumber Daya Manusia- Edisi Ketiga. Jakarta: Ghalia Indonesia.

Wibowo. (2017). Manajemen Kinerja-Edisi Kelima. Depok: RajaWali Press. 